\title{
Badania wizualne powierzchni wewnętrznej luf armat czarnoprochowych
}

\author{
Visual testing internal area barrels black powder
}

\section{Streszczenie}

Artykuł przedstawia ogólną charakterystykę diagnostyki luf armat czarnoprochowych. Do badań zastosowano metodę wizualną opartą o wykorzystanie jednego z rodzajów endoskopu jakim jest wideoendoskop. W artykule opisano stanowisko wideoendoskopowe wykorzystywane do badań i diagnostyki różnego rodzaju luf. Diagnostyka stanu technicznego luf armat czarnoprochowych w postaci wizualnych badań nieniszczących pozwala na kompleksową wizualizację powierzchni wewnętrznej badanej lufy. Dodatkowe wyposażenie w połączeniu z oprogramowaniem pozwala dokładnie zwymiarować wykryte nieciągłości zarówno liniowe, jak i powierzchniowe. Ostatecznie badanie takie, pozwala na określenie stanu technicznego badanej lufy i jej zdatności do dalszej eksploatacji.

W artykule przedstawiono obrazy z badań luf czarnoprochowych, ich stan powierzchni bezpośrednio po eksploatacji (po strzelaniu) i stan wewnętrznej powierzchni lufy wyczyszczonej i przygotowanej do badań.

Słowa kluczowe: lufa armaty czarnoprochowej; diagnostyka techniczna; badania wizualne; endoskop

\begin{abstract}
The article presents the general characteristics of diagnostic barrels of black powder guns. The study's method was used for visual based on the use of one of the endoscope that is the video- endoscope. The article describes the position video endoscopes used for research and diagnosing various types of barrels. Diagnostics of technical condition of the barrels of guns black powder in the form of visual NDT allows for complete visualization of the surface of the inner barrel studied. Additional equipment in conjunction with the software allows accurate - not dimensioned detected discontinuities both linear and superficial. Finally, such an examination, allows you to determine the status of the technical study of the barrel and its suitability for further use.

The article presents images from the barrels of black powder research, their surface condition immediately after use (after the shooting) and the condition of the inner surface of the barrel cleaned and prepared for testing.
\end{abstract}

Keywords: barrel black powder; technical diagnostics; visual testing; endoscope

\section{Wstęp}

NDT (Non-Destructive Testing - NDT) jest podzielona na różne metody badań nieniszczących, z których każda opiera się na konkretnej zasady naukowej [7]. Metody te mogą być dalej podzielone na różne techniki. Różne metody i techniki, ze względu na ich szczególne natury, mogą szczególnie dobrze nadają się do pewnych wniosków i mieć niewielką lub żadną wartość w ogóle w innych aplikacjach. Dlatego wybór odpowiedniej metody i techniki jest ważną częścią wykonywania badań nieniszczących tzn. inspekcji.
Badania nieniszczące luf armat zarówno gwintowanych, jak i gładkolufowych (w tym czarnoprochowych) są rodzajem badań, w wyniku których, bez wpływu na własności strukturalne i powierzchniowe luf, oceniony zostaje stan techniczny badanych luf [1].

Badania nieniszczące to badania, umożliwiające uzyskanie informacji o stanie fizycznym, wadach i własnościach badanego obiektu - lufy bez spowodowania zmiany jego cech użytkowych [6]. Badania mające na celu

Kmdr por dr Mirosław Chmieliński, kmdr por. dr inż. Artur Cywiński, kmdr por rez. mgr inż. Mirosław Gołyga - Akademia Marynarki Wojennej, mgr inż. Szymon Kubisiak - OLYMPUS Polska Sp. z o.o., Adam Majrzak - Kurkowe Bractwo Strzeleckie Zabrze, Andrzej Giecewicz - Kurkowe Bractwo Strzeleckie Gdynia, Konrad Jakubowski - Kurkowe Bractwo Strzeleckie Sieradz.

Autor korespondencyjny/Corresponding author. szymon.kubisiak@olympus-europa.com 
wykrycie wad typu nieciągłości materiału są nazywane badaniami defektoskopowymi i pozwalają ocenić na ile powierzchnia badana nadaje się do dalszej eksploatacji lub na ile w wyniku przeprowadzonych prac (np. konserwacji) jej stan się poprawił. Badania nieniszczące stanowią też źródło podstawowych informacji niezbędnych dla podjęcia decyzji dotyczących akceptacji badanej lufy lub decyzji diagnostycznych (opinia techniczna), związanych z jej dalszą eksploatacją. Z tego powodu niezwykle istotną cechą badań nieniszczących jest ich wiarygodność związana z powtarzalnością i odtwarzalnością, które w znacznym stopniu zależą od jakości dokumentów ustalających przebieg procesu badania [12]

\section{Ogólna charakterystyka badań diagnostycznych luf armat czarnoprochowych}

Jedną z metod NDT [8] wykorzystywanych w badaniach luf jest metoda endoskopowa, która jako bezdemontażowa metoda realizacji przeglądu wizualno-optycznego, pozwala na badanie przestrzeni luf armat, w tym czarnoprochowych, wewnętrznych przy wykorzystaniu takich przyrządów wziernikowych jak endoskopy (boroskopy, fiberoskopy czy wideoendoskopy).

W Akademii Marynarki Wojennej w Gdyni na stanowisku szkolno-badawczym przezna-czonym do prowadzenia badań nieniszczących (wizualnych) luf armat morskich

dokonano badań luf armat czarnoprochowych z wykorzystaniem wideoendoskopu [2].

Badania nieniszczące luf armat czarnoprochowych wykonywane są w celu określenia aktualnego ich stanu technicznego: wykrycia zużycia lub uszkodzenia luf, jak również w celu wyeliminowania przyczyn niesprawności, dla zapewnienia bezpiecznej eksploatacji luf armat czarnoprochowych. Dokładna wizualna analiza powierzchni połączona z historią eksploatacji armaty pozwala niejednokrotnie określić przyczynę występującej nieciągłości lub pojawiającej się wady $[9,10]$.

Prostota badania przy użyciu wideoendoskopu i jak wspomniano bezdemontażowość pozwala na przeprowadzenie badań wizualnych na dowolnym etapie procesu remontu czy też konserwacji luf. Badania te można przeprowadzać również po wszelakich pracach konserwcyjnych celem sprawdzenia stanu obrobionej powierzchni.

W skład stanowiska wideoendoskopowego wchodzą:

1) urządzenia diagnostyczne przeznaczone do oceny stanu technicznego armat (luf) - IPLEX LX (rys. 1 i 2);

2) urządzenie do czyszczenia luf armat czarnoprochowych;

3) narzędzia i materiały do obsługi luf armat czarnoprochowych;

4) urządzenia do rejestracji, archiwizacji i wizualizacji badań luf armat czarnoprochowych[4].

Zastosowane rozwiązanie umożliwia nagrywanie obrazów widocznych podczas badań luf armat czarnoprochowych oraz ich rejestrowanie.

Urządzenie do sprawdzenia stanu technicznego i stopnia zużycia umożliwia dokonanie sprawdzenia powierzchni wewnętrznej lufy o różnych średnicach (kalibrach), a spełnia następujące funkcje, wymagania i możliwości:

- badania wnętrza lufy armaty czarnoprochowej z określeniem lokalizacji oraz wielkości wady;

- analizowanie, dokumentowanie i archiwizowanie defektów lufy;

- bezpieczne przenoszenie i przewożenie przyrządu (umieszczenie przyrządu i jego elementów w pojemniku transportowym);
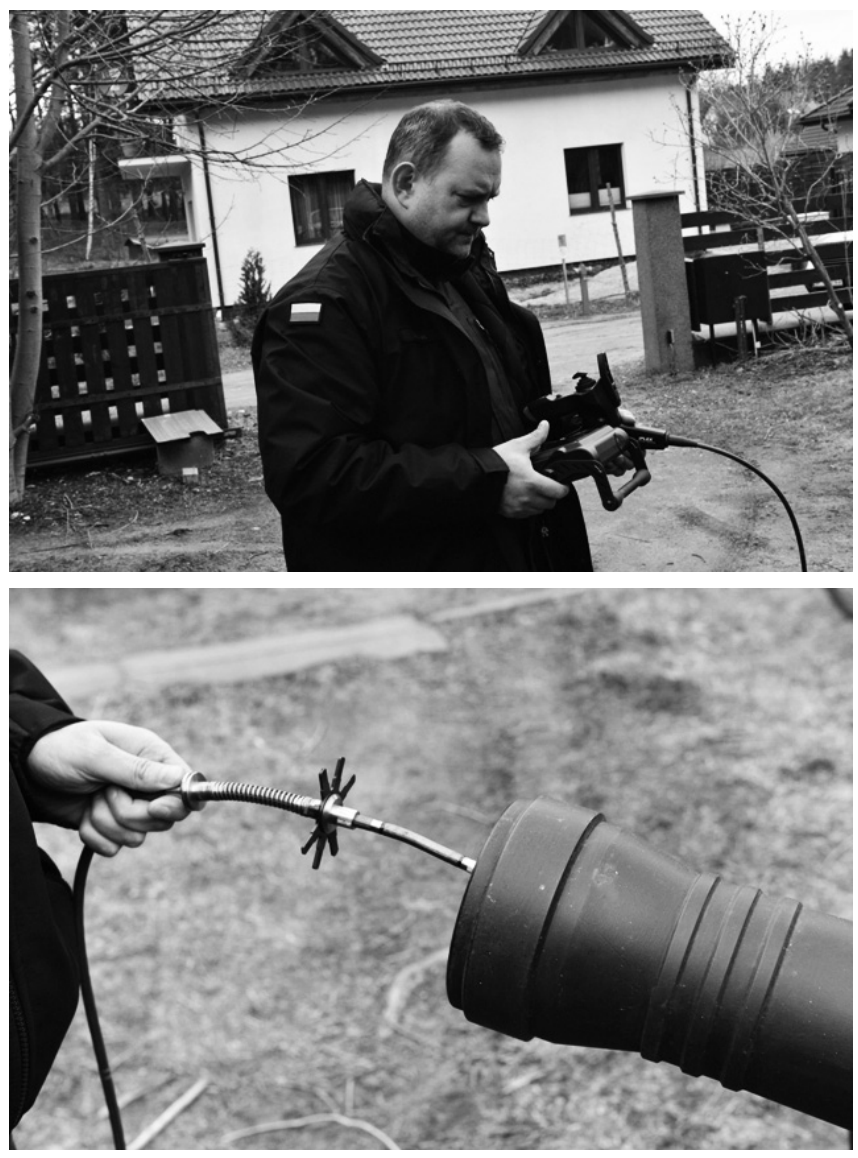

Rys. 1 i 2. Wideoskop IPLEX LX na stanowisku badań endoskopowych. Źródło: Archiwum foto autora

Fig. 1 and 2. The IPLEX LX during testing. Source: Foto author archives.

- obraz "na żywo” przedstawiony na monitorze pozwala na dokładny widok ścian luf armat czarnoprochowych wewnątrz, umożliwiając szybką diagnozę wstępną;

- urządzenie umożliwia pełny podgląd uszkodzeń;

- umożliwia pomiar interaktywny z powłoką wielokrotną i funkcjami adnotacyjnymi, (skala, tekst, data, itp.);

- umożliwia zapisywanie i archiwizowanie wyników pomiarów;

- umożliwia porównywanie obrazów archiwalnych i „na żywo".

W celu potwierdzenia przydatności stanowiska do szybkiej diagnostyki i ustalenia przydatności luf armat czarnoprochowych do dalszej eksploatacji - wykonywanej podczas jego obsługi - dokonano badań luf armat czarnoprochowych (rys. 3 i 4).

Badania endoskopowe luf armat czarnoprochowych powinny być wykonywane w następujących sytuacjach:

- w czasie realizacji przeglądów profilaktycznych (co najmniej raz w roku), które powinna obejmować niezbędny zakres i chronologię prowadzenia przeglądów przestrzeni wewnętrznych, umożliwiających wykrycie defektów poszczególnych elementów i układów funkcjonalnych;

- przy bieżącej ocenie stanu technicznego, itp.

Podczas badania ocenie podlegają w szczególności:

- pęknięcia, rysy oraz ubytki materiału;

- intensywność procesów zanieczyszczenia i zużycia przewodu lufy;

- lokalne ogniwa korozji oraz erozji powierzchniowej lufy [11]. Pełen cykl badań wizualnych (Visual Testing - VT) składa się z zapoznania się z badanymi lufami armat czarnoprochowych oraz wymaganiami jakościowymi, przygotowania powierzchni do badań, doboru odpowiedniej aparatury, sprawdzenia wyposażenia badawczego, przeprowadzenia badania oraz sporządzenia raportu [8]. 

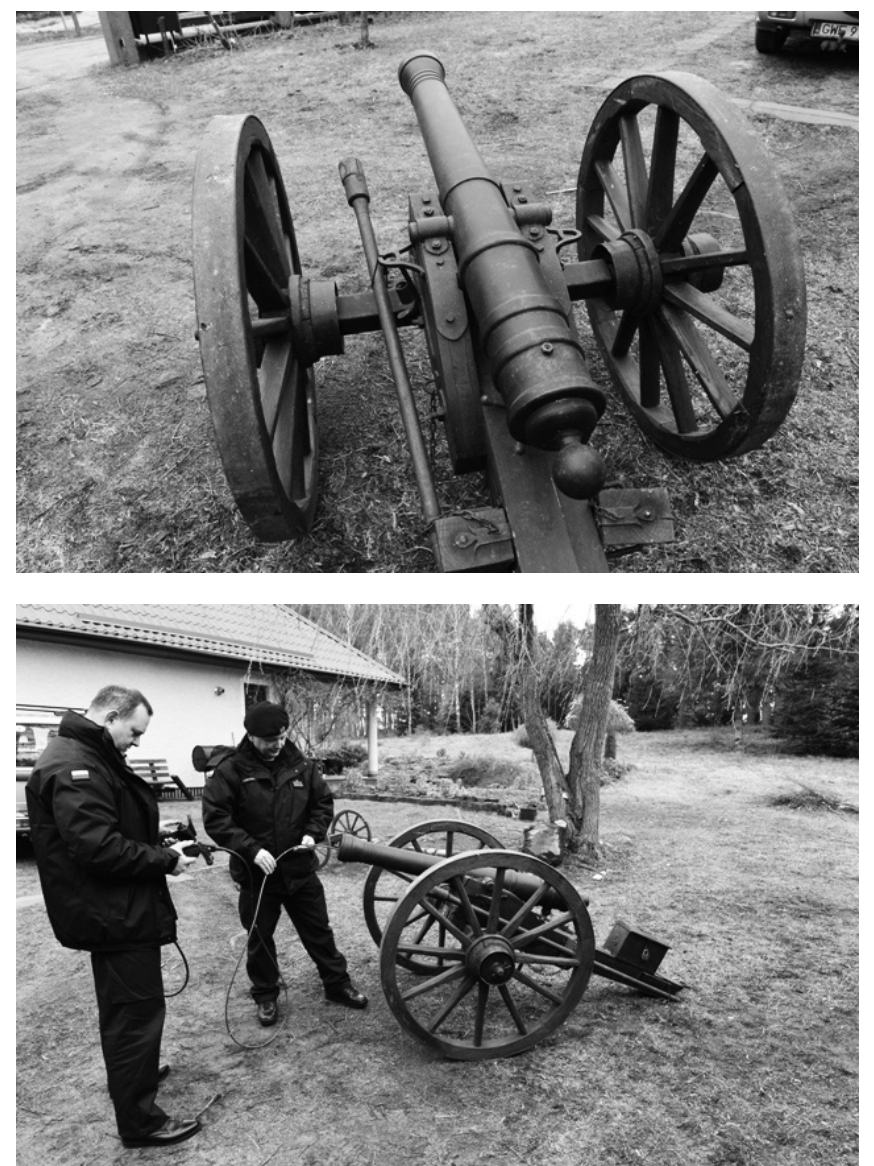

Rys. 3 i 4. Armata czarnoprochowa i wideoskop IPLEX LX na stanowisku badań. Źródło: Archiwum foto autora.

Fig. 3 and 4. Black powder cannon and the IPLEX LX during testing Source: Foto author archives.

Stanowisko badawcze wyposażone jest $\mathrm{w}$ wideoendoskop IPLEX LX [13], urządzenie wykonujące w sposób automatyczny czyszczenie lufy, polegające na usuwaniu zanieczyszczeń, smarów i produktów korozji z powierzchni wewnętrznej przewodu lufy, analizator pomiarowy do wizualizacji wyników badań diagnostycznych z możliwością zarządzania wydrukami protokołów i raportów oraz przesyłania on-line wyników oraz materiały do obsłu-
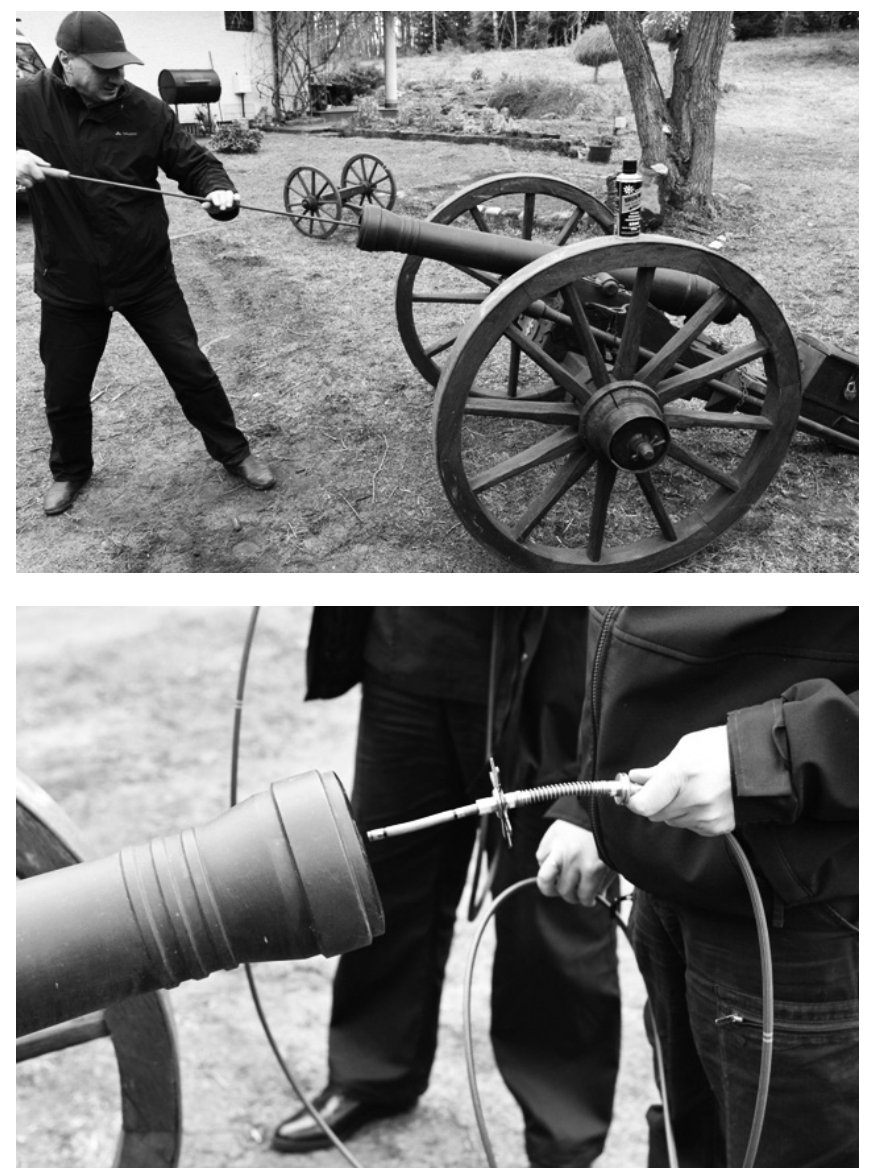

Rys. 8 i 9. Wideoskop IPLEX LX na stanowisku badań endoskopowych. Źródło: Archiwum foto autora.

Fig. 8 and 9. The IPLEX LX during testing. Source: Foto author archives.

gi luf armat czarnoprochowych. Podczas badania ocenie podlegają procesy zanieczyszczenia i zużycia przewodu lufy w tym pęknięcia, rysy oraz ubytki materiału, intensywność występowania ogniw korozji oraz erozji powierzchniowej lufy.

Badania endoskopowe luf armat czarnoprochowych wykonywał przeszkolony personel posiadający wykształcenie techniczne oraz doświadczenie w pracy zawodowej

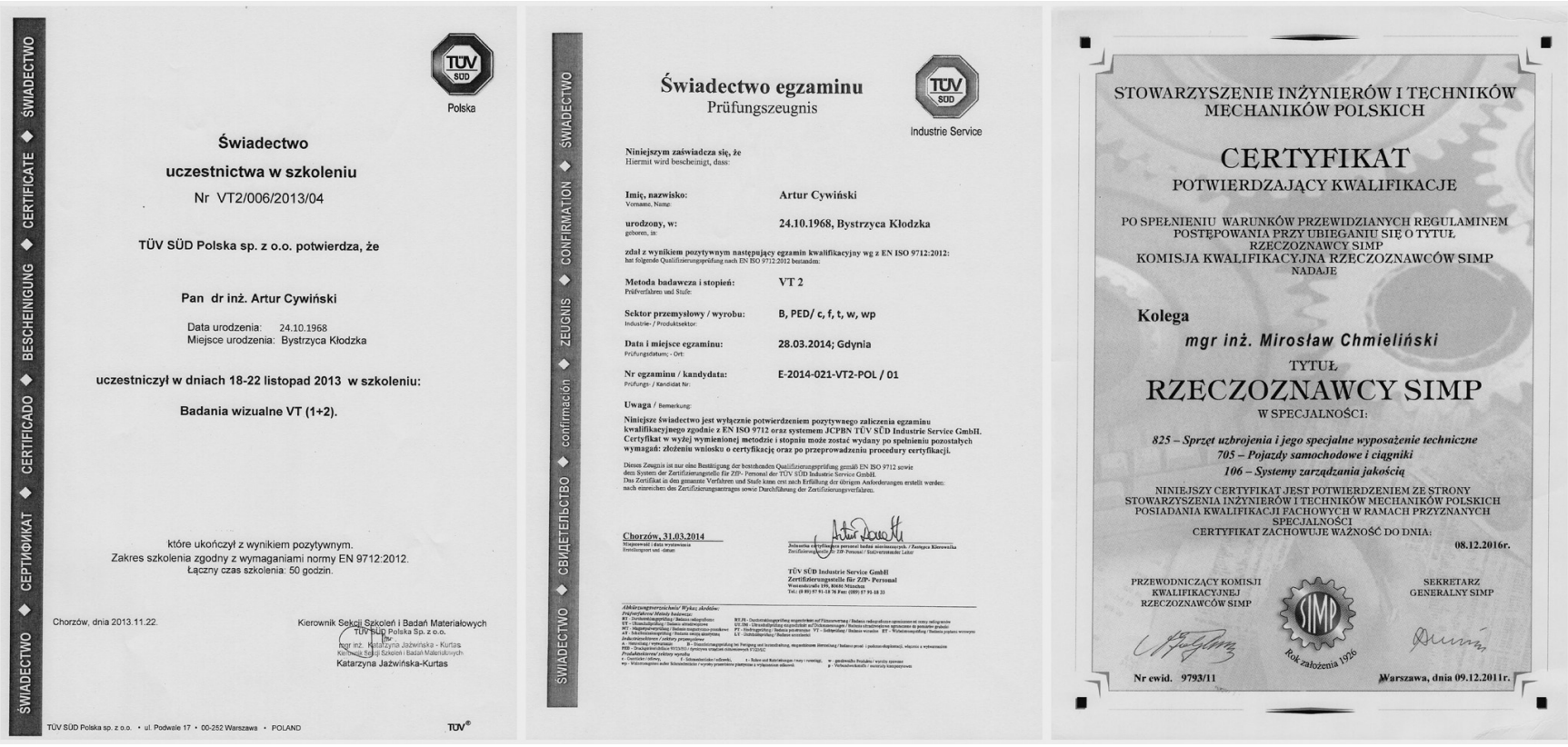

Rys. 5:7. Świadectwo ukończenia szkolenia VT oraz świadectwo egzaminu oraz Certyfikat Dyplomowanego Rzeczoznawcy SIMP w specjalności Uzbrojenie i sprzęt wojskowy. Źródło: Archiwum foto autora.

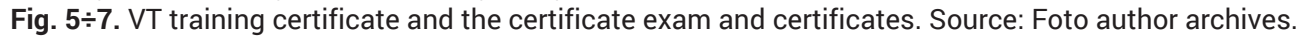


z uzbrojeniem. Warunkiem niezbędnym do prowadzenia wiarygodnych pomiarów było uzyskanie odpowiednich

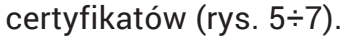

Taka nieinwazyjna metoda diagnostyczna luf armat czarnoprochowych może pozwolić na ustalenie przydatności luf armat czarnoprochowych do dalszej eksploatacji, podczas wykonywania ich przeglądu (rys. 8 i 9). Taka nieinwazyjna metoda diagnostyki luf armat czarnoprochowych pozwala na szybkie i dokładne określenie ich aktualnego stanu technicznego - bez ich demontażu.

Urządzenia i endoskopowe (wizualne) techniki diagnostyczne są szczególnie przydatne w sytuacjach, gdy sprawdzenie stanu technicznego luf armat czarnoprochowych odbywa się w miejscach trudnodostępnych, a sam proces sprawdzenia jest utrudniony i czasochłonny.

Zastosowanie badań endoskopowych luf armat czarnoprochowych pozwala na ocenę stanu technicznego bez konieczności częściowego demontażu w/w sprzętu. Dzięki badaniom endoskopowym przeprowadzanym w ramach badań, możliwe jest odpowiednio szybkie wykrycie wszelkich uszkodzeń oraz ich rozmiaru, co pozwoli zapobiec poważniejszym awariom lub wypadkom. Przykładowe obrazy stanu powierzchni wewnętrznej lufy czarnoprochowej przedstawiają rysunki 10 i 11.
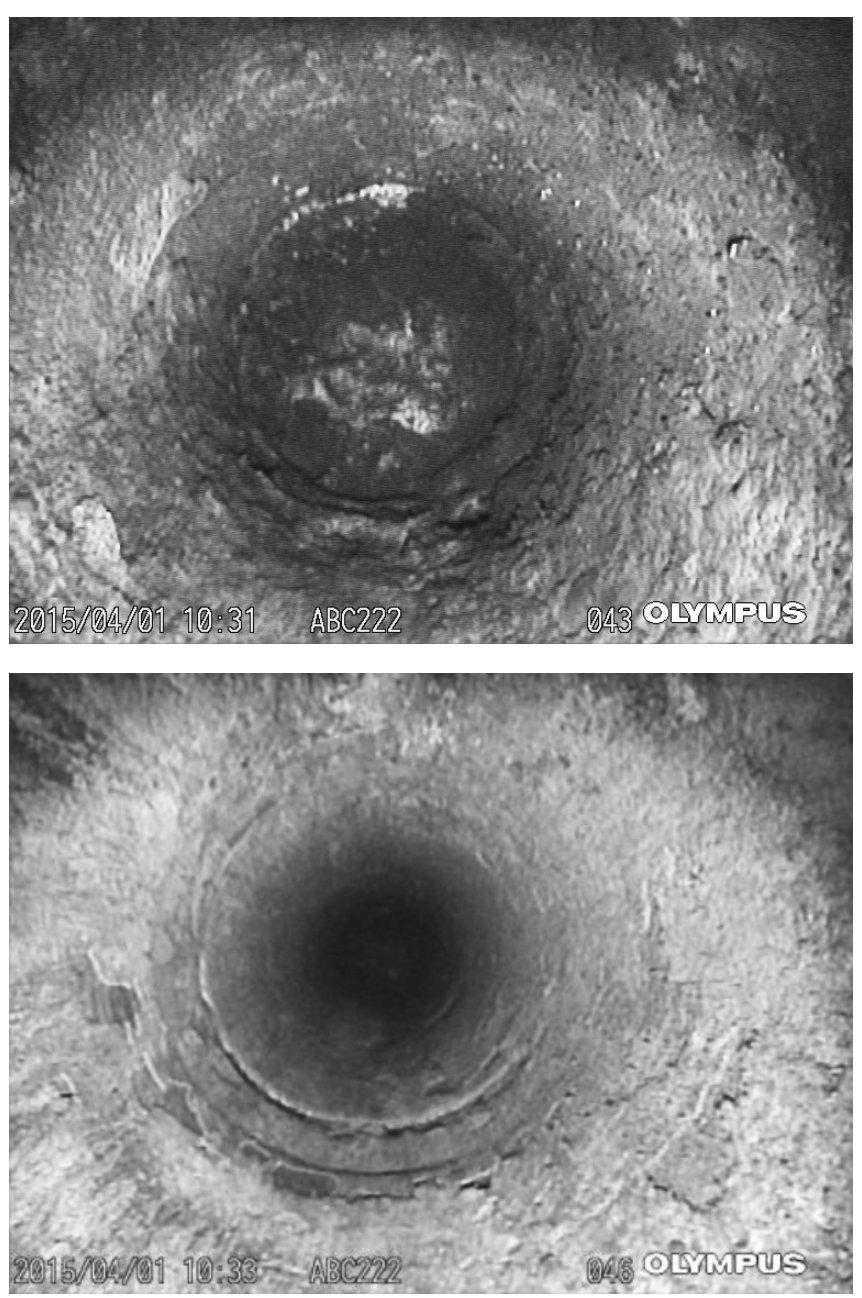

Rys. 10 i 11. Powierzchnie wewnętrzne lufy armaty czarnoprochowej. Źródło: Archiwum foto autora.

Fig. 10 and 11. The internal area barrel of black powder guns. Source: Foto author archives.

Przedstawione powyżej rysunki 10 i 11 prezentują stan powierzchni wewnętrznych luf przed właściwym przygotowaniem ich do pracy czyli po eksploatacji. Podstawą wykonania prawidłowych badań wizualnych - endoskopowych jest właściwe przygotowanie powierzchni wewnętrz- nej luf armat czarnoprochowych. Przygotowanie polega na usunięciu zanieczyszczeń, smarów, produktów korozji itp. w taki sposób, aby nie została naruszona pierwotna postać tej powierzchni lub przynajmniej nie zostały zamaskowane (zakryte) takie wady powierzchniowe, które powinny być wykryte w czasie badań.

\section{Brunox preparaty do czyszczenia i konserwacji luf armat czarnoprochowych}

Czyszczenie i konserwacja wewnętrznej powierzchni luf armat czarnoprochowych, to bardzo obszerny temat i zagadnienia, powód wielu dyskusji nie tylko w rozległym świecie kolekcjonerów, ale i zbieraczy oraz poszukiwaczy. Czym jest konserwacja lufy armaty czarnoprochowej? A mianowicie sprowadza się ona do jednego prostego priorytetu - postarać się zachować jak najdłużej i w jak najlepszym stanie lufę, tak aby mogła być eksploatowana przez długi okres bezawaryjnie. Samych metod czyszczenia i konserwacji lufy jest kilka.

Jeśli lufa armaty czarnoprochowej została użyta do strzelania, potrzebny jest środek rozpuszczający osady powstałe na skutek spalenia prochu oraz usuwające pozostałości stopów miedzi lub ołowiu. Niestety, ołów najlepiej usuwa się mechanicznie. Środki chemiczne potrafią ołowiane pozostałości jedynie zmiękczyć, więc najlepiej użyć w tym wypadku dobrych szczotek drucianych. Jeśli szczotkę prowadzimy w cyklach - tam i z powrotem, to pamiętajmy, aby cała szczotka opuściła przewód lufy, zanim przeciągniemy ją z powrotem. Dzięki temu druty będą mogły się rozprostować i szczotka dłużej nam posłuży. Wycior trzeba trzymać za rączkę, umożliwiając mu swobodne obracanie. Lufę czyścimy od strony komory zamkowej, prowadząc przecierak lub filc tylko w kierunku wylotu lufy. Odstępstwem od tej reguły może być użycie szczotek metalowych, jednak przed rozpoczęciem powrotnego ruchu wycioru, cała szczotka musi opuścić lufę. Niedopuszczalne jest zaaplikowanie znacznej ilości środka czyszczącego lub konserwującego do lufy i pozostawienie broni stojącej pionowo w szafie czy stojaku. Środek ten będzie swobodnie spływał i skapywał na zamek lub osadę, co w skrajnych przypadkach może doprowadzić do uszkodzenia broni. BRUNOX GUN CARE SPRAY (rys. 12 i 13) przeznaczony jest do czyszczenia i konserwacji wszelkiego rodzaju broni.
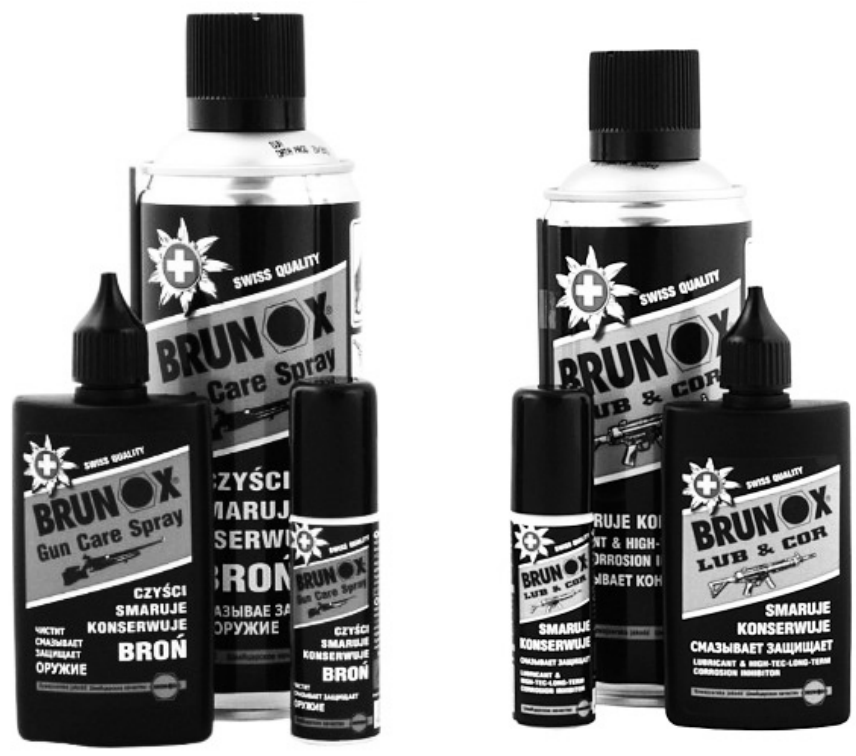

Rys. 12 i 13. Brunox Gun Care Spray oraz Brunox Lub \& Cor. Źródło: fot. K.T.J. Kolor Sp. z o.o.

Fig. 12 and 13. Brunox Gun Care Spray and Brunox Lub \& Cor. Source: Foto K.T.J Ltd. 
Czyści, smaruje i pielęgnuje wszystkie metalowe części broni. Usuwa pozostałości prochu, ołowiu, tombaku, miedzi czy niklu. Tworzy cienką, nielepką, niezasychającą ochronną powłokę. Chroni również przed potem i wilgocią. Nie zawiera silikonu, teflonu i grafitu. Jest neutralny dla gumy, plastiku, lakierów, drewna i skóry. Dodatek substancji TURBOLINE za-pewnia długotrwałe działanie. Temperatura zamarzania poniżej $-50{ }^{\circ} \mathrm{C}$. Polecany dla użytkow-ników jak i kolekcjonerów broni. Posiada specyfikację NATO S-761 i spełnia normę DIN 50021. Brunox Gun Care Spray został przetestowany przez producenta pistoletu P99, firmę Carl Walther GmbH\&Co. Preparat jest oficjalnie polecany do konserwacji tej broni.

Czynności podczas czyszczenia lufy armaty czarnoprochowej:

1. Należy nanieść preparat Brunox ${ }^{\circledR}$ Gun Care Spray do lufy, rozprowadzić wyciorem. Poczekać 3-5 minut.

2. Wyciągnąć brud przy użyciu wyciora i szmatki z tkaniny.

3. Kiedy szmatka po kilku powtórzeniach jest już czysta, należy nanieś na nią preparat Brunox ${ }^{\circledR}$ Gun Care Spray i raz jeszcze wprowadź ją do lufy.

4. Lufa jest czysta, nasmarowana i gotowa do użycia. Nie ma potrzeby usuwania preparatu z lufy.

Nadmiar preparatu może być bardziej szkodliwy niż jego brak. Zwłaszcza zimą, gdy nadmiar oleju może pod wpływem ujemnej temperatury żelować lub zamarznąć, utrudniając lub uniemożliwiając pracę mechanizmów. Dlatego w technice czyszczenia i konserwacji lufy trzeba wprowadzać nowoczesne, technologicznie zaawansowane preparaty, które rozwiązują wskazane wyżej problemy.

Propozycja szwajcarskiej firmy BRUNOX jest tego dowodem. Charakterystyki techniczne tych preparatów powinny zainteresować najbardziej zaangażowanych
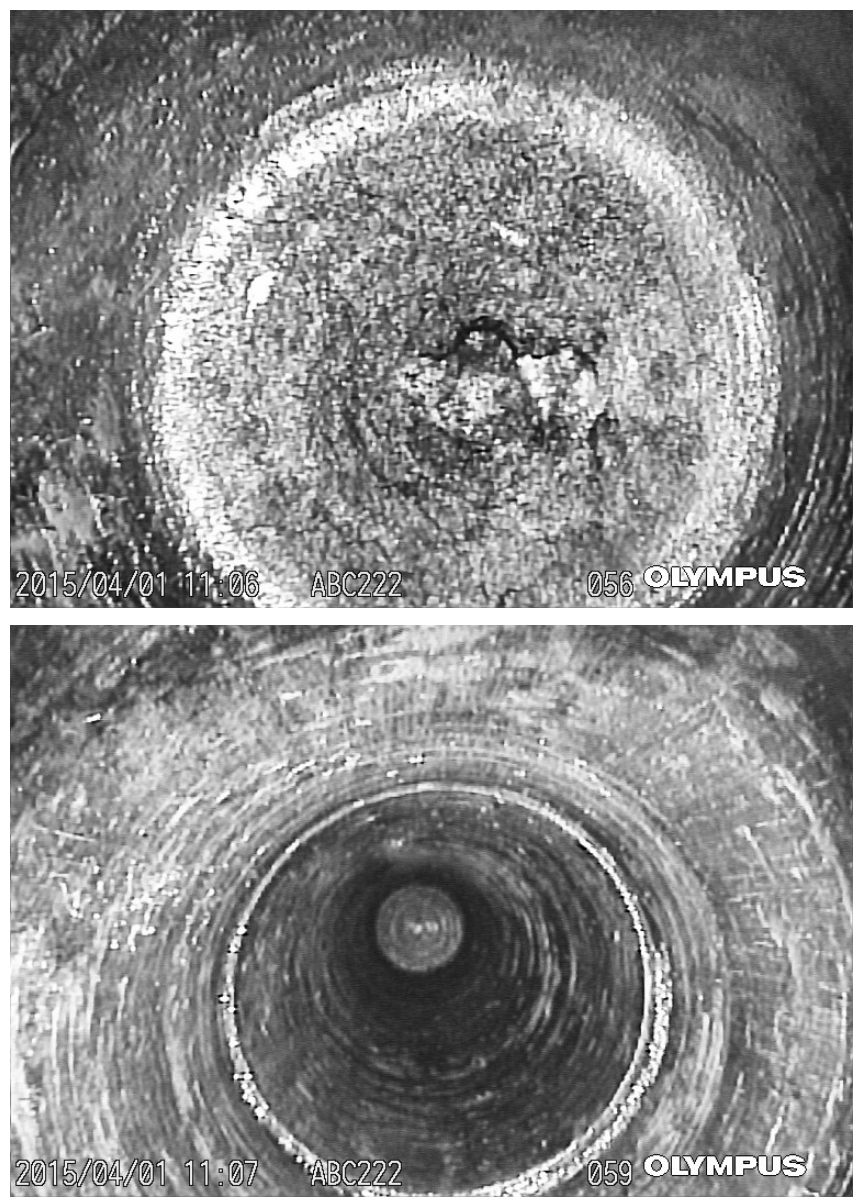

Rys. 14 i 15. Powierzchnie wewnętrzne lufy armaty czarnoprochowej po przygotowaniu do badań. Źródło: Archiwum foto autora.

Fig. 14 and 15. The internal area barrel of black powder guns after the preparation of testing. Source: Foto author archives. użytkowników. BRUNOX Lub\&Cor - Mocno przylegający preparat antykorozyjny polecany szczególnie dla profesjonalistów takich jak wojsko, policja czy straż graniczna, w przypadkach gdy broń jest poddana działaniu niekorzystnych warunków atmosferycznych, a musi pozostać w ciągłej gotowości do użycia.

Brunox ${ }^{\circledR}$ LUB\&COR chroni lufy armaty czarnoprochowej przed korozją przez około rok, gdy ta znajduje się na zewnątrz, ale pod dachem. Na otwartej przestrzeni broń jest chroniona przez około pół roku, a w pomieszczeniach nawet do trzech lat. Preparat tworzy równomierną, nieschnącą, ochronną powłokę antykorozyjną o grubości 5-10 mm. Jest idealnym smarem dla broni długiej, półautomatycznej i maszynowej. Temperatura zamarzania poniżej $-41^{\circ} \mathrm{C}$.

Analiza stanu wnętrza badanej, przykładowej lufy armaty czarnoprochowych wykazała na występowanie licznych ognisk korozji. Są to defekty wskazujące na utlenianie się wewnętrznej powierzchni lufy armaty czarnoprochowej, zwłaszcza w miejscach, w których wystąpiły uszkodzenia mechaniczne podczas eksploatacji. W analizowanym przykładzie zlokalizowano i rozpoznano co najmniej trzy ogniska korozji, charakteryzujące różne stany degradacji powierzchni wewnętrznej lufy armaty czarnoprochowej, tj. korozję punktową, plamową i wżerową.

Lufy armat czarnoprochowych pracują w warunkach określanych, jako środowisko gazowe (żrące) oraz w wa-
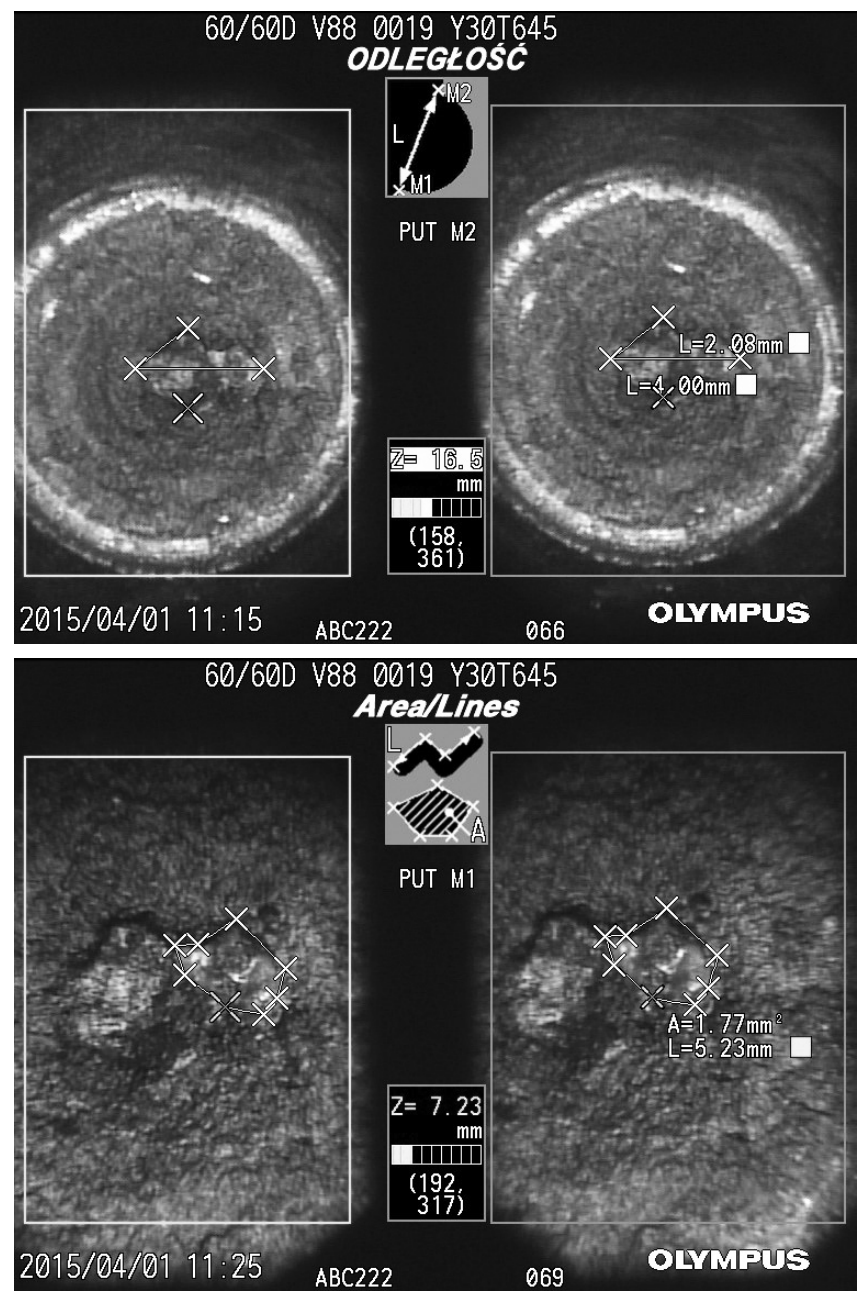

Rys. 16 i 17. Badanie lufy czarnoprochowej z analizą wielkości defektów na powierzchni dna komory przewodu lufy. Źródło: Archiwum foto autora.

Fig. 16 and 17. The visual inspection barrel of black powder with analysis of the size of defects on the area of the barrel conduit. Source: Foto author archives. 
runkach gwałtownych zmian ciśnienia i temperatury. Stąd występujące naprężenia i zmęczenie techniczne materiału prowadzą utleniania się powierzchni, a następnie pękania i łuszczenia się warstw skorodowanych. W konsekwencji prowadzi to do powstawania uszkodzeń mechanicznych i strukturalnych wewnętrznej powierzchni lufy armat czarnoprochowych.

W pracy nowoczesnego, specjalistycznego laboratorium badań nieniszczących luf armat czarnoprochowych jednym z kluczowych zagadnień są wymagania i oczekiwania wobec pracy specjalisty, który powinien znaleźć odpowiedzi na pytania prowadzące do podejmowania i rozwiązywania nietypowych problemów badawczych, kończących się sporządzeniem opinii bądź ekspertyzy o stanie technicznym luf armat czarnoprochowych [4].

Przeprowadzane badanie pozwalają na ustalenie przydatności luf armat czarnoprochowych do eksploatacji. Badania nieniszczące luf armat czarnoprochowych wykonywane są w celu określenia aktualnego ich stanu technicznego lub wykrycia przyczyn zużycia lub uszkodzenia luf, jak również w celu wyeliminowania przyczyn niesprawności, dla zapewnienia bezpiecznej eksploatacji luf armat czarnoprochowych.

Badania za pomocą wideoendoskopu prowadzone są w różnych warunkach, często poza pomieszczeniami, na otwartym powietrzu. Wymagane jest, by odbywały się w atmosferze wolnej od kurzu, brudu i opadów atmosferycznych[3].

Wyklucza się obecność gazów agresywnych ujemnie wpływających na układy optyczne oraz palnych i wybuchowych.

Aparatura zastosowana do badań luf armat czarnoprochowych dokonanych w Pracowni Broni Rakietowej i Artylerii AMW (PBRiA AMW) posiada niewielką masę i zasilanie akumulatorowe. Kompletny system, łącznie $z$ akcesoriami i walizką, można przenosić na kolejne miejsca pracy, w prawie każdych trudnych warunkach. Zdaniem producenta modele te mogą być używane podczas deszczu, w piasku i pyle, wytrzymują wstrząsy fizyczne spowodowane upuszczeniem [1].

\section{Podsumowanie}

W eksploatacji luf armat czarnoprochowych coraz powszechniej są już wykorzystywane nowe metody badań diagnostycznych, a w szczególności badania endoskopowe. Nieinwazyjne metody diagnostyczne pozwalają na ustalenie przydatności luf armat czarnoprochowych do dalszej eksploatacji, podczas wykonywania jego obsługi. Szczególnie dużą przydatność mogą wykazywać w trudno dostępnych miejscach.

Badania endoskopowe pozwalają na ocenę stanu technicznego luf armat czarnoprochowych bez konieczności częściowego demontażu ww. sprzętu.

Przeprowadzenie badań diagnostyki endoskopowej każdego rodzaju luf, w tym luf armat czarnoprochowych wymaga od operatora dużego doświadczenia w zakresie analizy i precyzowania wniosków z badań [5].

W porównaniu z lufami gwintowanymi lufy czarnoprochowe są trudniejsze do diagnostyki ze względu na jednolitą powierzchnię wewnętrzną (brak pól i bruzd).

Brak jest jednoznacznych zapisów, w tym norm, pozwalających określić na ile określony defekt może być przyczyną wyłączenia z eksploatacji danej lufy. W przypadku większości luf eksploatowanych w Wojsku Polskim określa się to w oparciu o przewidzianą dla lufy dopuszczalną liczbę wystrzałów. Przekroczenie tego wskaźnika decyduje o dalszym wyłączeniu lufy z eksploatacji.

Metoda endoskopowa w przypadku luf czarnoprochowych pozwala na wykrycie najbardziej niebezpiecznych nieciągłości jakimi są nieciągłości powierzchniowe płaskie i wąskoszczelinowe. W przypadku konieczności dokonania dokładnej analizy innych prawdopodobnych nieciągłości koniecznym jest zastosowanie metod objętościowych jak np. ultradźwiękowe czy radiograficzne lub powierzchniowe (prądów wirowych, magnetyczno-proszkowa czy penetracyjna) [12].

Zapewnienie poprawnego rozwoju diagnostyki technicznej luf wszystkich armat czarnoprochowych będących przedmiotem tej diagnostyki jest wyraźnie sprecyzowane i oczekuje na szybkie wdrożenia.

\section{Literatura}

[1] Chmieliński M., Jurczak W., Kubisiak Sz., Lipnicki M., Pojawa B.: Laboratoria badawcze NDT w procesie zapewnienia bezpieczeństwa wyrobów techniki wojskowej. VIII Międzynarodowa Konferencja „Laboratoria badawcze, systemy jakości w Unii Europejskiej”, Łagów/Brandenburgia 11-14 czerwca $2014 \mathrm{r}$.

[2] Chmieliński M., Kobus $Ł$.: Wybrane badania diagnostyczne uzbrojenia i sprzętu wojskowego za pomocą przyrządów endoskopowych, $\mathrm{Nr} 2$ (168) Zeszyty Naukowe WSO Wrocław 2013.

[3] Chmieliński M., Gołyga M., Kubisiak Sz.: Diagnostyka stanu technicznego luf artyleryjskich przy wykorzystaniu wideoskopów, VI Międzynarodowa Konferencja Naukowo-Techniczna „Technologie morskie dla obronności i bezpieczeństwa", Gdańsk 24-26 czerwca 2014 r.

[4] Chmieliński M., Kubisiak Sz., Cywiński A.: Sporządzanie ekspertyz i opinii technicznych w oparciu o badania wizualne luf artyleryjskich Przegląd Spawalnictwa 2015, Vol. 87, $\mathrm{nr} 12$.

[5] Chmieliński M., Kubisiak Sz.: Nowoczesne badania nieniszczące luf armat morskich pod-stawą bezpieczeństwa eksploatacji techniki wojskowej. Przegląd Spawalnictwa 2014, Vol. 86, nr 11
[6] Chmieliński M., Milewski S., Pojawa B.: Nowoczesne metody badań diagnostycznych uzbrojenia okrętowego i sprzętu wojskowego. Zeszyty Naukowe AMW 172B. Publikacje z zakresu „Kierowania ogniem systemów obrony powietrznej przeciwlotniczej), Gdynia 2008r.

[7] PN-EN 1330-2 Badania nieniszczące - Terminologia - Terminy wspólne dla badań nieniszczących.

[8] PN-EN 1330-10 Badania nieniszczące - Terminologia - Część 10: Terminy stosowane $w$ badaniach wizualnych.

[9] PN-EN 13018 Badania nieniszczące - Badania wizualne - Zasady ogólne. [10] PN-EN 13927 Badania nieniszczące - Badania wizualne - Wyposażenie.

[11] No-10-A009:2005 Broń artyleryjska - Rodzaje i podstawowe cechy - Terminologia.

[12] Praca zbiorowa pod redakcją Lipnicki M.: Badania metodami nieniszczącymi, Poradnik dla inspektorów, PRS/Koli, Gdańsk 1991.

[13] http://www.olympus-ims.com/pl 